\title{
EFFECT OF SEEPAGE ON CHANGE IN STRESS DISTRIBUTION SCENARIO IN STATIC AND SEISMIC BEHAVIOUR OF EARTHEN DAMS
}

\author{
N. NANDI ${ }^{*}$ and A. ROYCHOWDHURY \\ AE and AM Department \\ IEST, Shibpur, INDIA \\ E-mail: nityananda@mailcity.com \\ S.C. DUTTA \\ C.E. Department \\ ISM, Dhanbad, INDIA
}

\begin{abstract}
The present study makes an effort to understand the damage of earthen dams under static and seismic loading condition. To make the investigation more realistic, behaviour of earthen dams considering the occurrence of a phreatic line indicating the submerged zone due to seepage within the dam body is considered. In case of earthen dams, homogeneous or nonhomogeneous, the consideration of the occurrence of a phreatic line or seepage line through the dam body is an important part of the earthen dam design methodology. The impervious material properties in the submerged zone below the phreatic line due to seepage may differ a lot in magnitudes as compared to the value of the same materials lying above this line. Hence, to have the exact stress distribution scenarios within the earthen dam, the different material properties above and below the phreatic line are considered in this present study. The study is first carried out by two-dimensional as well as three-dimensional finite element analysis under static loading condition. The work is further extended to observe the effect of seepage due to the consideration of the phreatic line on dynamic characteristics of earthen dams. Free vibration analysis and seismic analysis based on the Complete Quadratic Combination (CQC) method by considering twodimensional and three-dimensional modeling are carried out to present the frequencies, mode shapes and the stress distribution pattern of the earthen dam.
\end{abstract}

Key words: complete quadratic combination method, harmonic load, finite element analysis.

\section{Introduction}

Consideration of seepage within earthen dams is a very crucial aspect of the dam design because damage of earthen dams due to piping is quite common. Instability of slopes, the seepage phenomenon plays a very crucial role by reducing the shear strength of the soil due to the existence of pore pressure. Though a large number of studies have been done on the behaviour of earthen dams [1-20], the issue of the occurrence of tension zone within the earthen dam body considering the occurrence of a phreatic line has not been studied earlier. It has been found in some of the previous studies [15-18] that the occurrence of tension zone at the crest level of earthen dams may be a crucial issue of the dam design methodologies. Hence, it is interesting to see whether the analysis considering the existence of the phreatic line within the dam body may also lead to the similar understanding regarding this aspect of the stress distribution scenario. An earthen embankment surrounding the Ash Pond of Bakreswar Thermal Power Project, West Bengal, is taken as an example dam for this analysis. Below the phreatic line the soil is assumed to be in submerged condition and accordingly the material properties are considered in this region. The stress distribution pattern within the dam body is observed under static loading condition. The study is extended considering the materially nonlinear properties by both two-dimensional and three-dimensional modeling. It is found in static analysis that the location of the tension zone is mainly concentrated around the phreatic line and approximately in the

\footnotetext{
${ }^{*}$ To whom correspondence should be addressed
} 
middle of the dam section. The study is further extended to see the effect of the consideration of the occurrence of the phreatic line on dynamic characteristics of earthen dams. Free vibration analyses as well as response spectrum based CQC analysis through two-dimensional and three-dimensional modeling are carried out to study the frequencies, mode shapes and stress distribution scenario within the dam body. The observations are finally summarized in the paper. Earlier studies [15-18] have indicated the possibilities of the occurrence of tension and subsequent cracking due to ground shaking purely based on analytical and computational procedures. The study [17] based on an experimental procedure also strengthens the possibility of occurrence of tension zone through gradual opening of longitudinal cracks.

The geometrical cross sections of this dam section have been changed to see whether these changed sections may be effective to change the stress distribution pattern after considering the occurrence of the phreatic line within the dam section. The original dam section is then modified by the steeper upstream slope, deep cut-off trench and the large widened lower berm. Both two-dimensional as well as threedimensional analyses are carried out to observe the stress zone for these modified sections. It has been shown that the geometrical cross-section may not have any influence to change the stress distribution pattern within the dam body even after the consideration of the seepage line.

\section{Modeling and analysis}

\subsection{Finite element modeling}

A six-noded triangular element is used for two-dimensional finite element analysis. The triangular element in two-dimensional modeling is particularly used to model the geometry with sufficient accuracy near the corner of such dams. To ensure accuracy further, a convergence study is carried out to arrive at adequate level of discretization.

A ten-nodded tetrahedron element is used for the three-dimensional finite element analysis. This element has quadratic displacement function and is suitable for irregular meshes. Details of the finite element modeling used in this study have been presented in the literature [15].

\subsection{Elasto-plastic analysis}

For this non linear analysis, a generalization of Mohr-Coulomb failure criterion as proposed by Drucker and Prager [21] is used as a yield criterion. This criterion is basically a modified Von-Mises criterion which is dependent on hydrostatic stress, $\sigma_{m}=1 / 3\left(\sigma_{x}+\sigma_{y}+\sigma_{z}\right)$ and can be expressed as

$$
3 \alpha\left(\sigma_{x}+\sigma_{y}+\sigma_{z}\right)+\left[\left(\sigma_{l^{-}} \sigma_{2}\right)^{2}+\left(\sigma_{2^{-}}-\sigma_{3}\right)^{2}+\left(\sigma_{3^{-}}-\sigma_{1}\right)^{2}\right]^{1 / 2}=\sigma_{y}
$$

where $\sigma_{x}, \sigma_{y}$ and $\sigma_{z}$ are stress components along the $x, y$ and $z$ directions, while $\sigma_{1}, \sigma_{2}$ and $\sigma_{3}$ are the principal stresses. This criterion is considered as a very suitable criterion that governs the shear failure in soil [21]. In this criterion while being used in ANSYS software, $\alpha$ is taken as $2 \sin \phi / \sqrt{3}(3-\sin \phi)$ and $\sigma_{y}=6 c \cos \phi / \sqrt{ } 3(3-$ $\sin \phi)$ where $c$ is the cohesion of soil and $\phi$ is the angle of internal friction [22]. However, since soil cannot take tension at all, an analysis based on this criterion considers the shear action as the only possible way of failure. But the present study shows that the occurrence of tension cannot be avoided and this can be well pointed-out by a linear analysis only. Thus, while carrying out nonlinear analysis with the above criterion, propagation of cracking due to tension perhaps cannot be recognized.

\subsection{CQC analysis}

For combining the contributions of all the possible lateral modes during the response spectrum based seismic analysis, the complete quadratic combination (CQC) method has been adopted. This CQC method is generally used to obtain the contribution of the modes with close-spaced natural frequencies with reasonable accuracy. If the combined modal response is denoted by $r_{0}$, then according to CQC rule 


$$
r_{o} \cong\left(\sum_{i=1}^{N} \sum_{n=1}^{N} \rho_{i n} r_{i o} r_{n o}\right)^{1 / 2}
$$

where, $r_{i o}$ and $r_{n o}$ are the peak responses of the $i$ th and $n$th mode, respectively, and $\rho_{i n}$ is the co-relation coefficient between these two modes; $\rho_{i n}$ varies between 0 to 1 and $\rho_{i n}=1$ for $i=n$. Thus the previous equation can be rewritten as

$$
r_{o} \cong\left(\sum_{n=1}^{N} r_{n o}^{2}+\sum_{i=1}^{N} \sum_{n=1}^{N} \rho_{i n} r_{i o} r_{n o}\right)^{1 / 2} .
$$

This method is used widely for different structures and the above equations are available in standard literature [23].

\subsection{Location of seepage line}

The prediction of the position of the seepage line within the cross section of the nonhomogeneous earthen dam with a very high accuracy is a complex problem. However, the procedure has been described in standard literature [24]. It has been realized that overall stress distribution scenario will not be affected considerably if the complex curvilinear geometry of the phreatic line is simplified to a straight line in such a way that the total submerged area below the phreatic line is not reduced. The distance EF along the downstream face of the earthen dam (Fig.1) has been calculated with the help of the equation

$$
E F=\frac{d}{\cos \beta}-\sqrt{\left(\frac{d^{2}}{\cos ^{2} \beta}-\frac{h^{2}}{\sin ^{2} \beta}\right)}
$$

where, $d, h$ and $\beta$ are well described in the figure. With the help of this Eq.(2.4) and the slope of the downstream face, the co-ordinate of the point $E$ has been calculated. The co-ordinate of the point $B$ is then calculated from known value of ' $h$ ' and the slope of the upstream face. Hence, the co-ordinates of the points 'B' and ' $E$ ' are now known. Also, the co-ordinates of the points L, M, G, and H are known. With the help of the above values, the co-ordinates of the points ' $\mathrm{C}$ ' and ' $\mathrm{D}$ ' are calculated. Now, B, C, D and $\mathrm{E}$ are joined by a straight line. This BCDE line represents the phreatic line within the dam section in a simplified form. With this simplification, the submerged area below the phreatic line is not getting reduced. Hence, the analysis using this model may be assumed to give reasonable results at least for the present purpose.

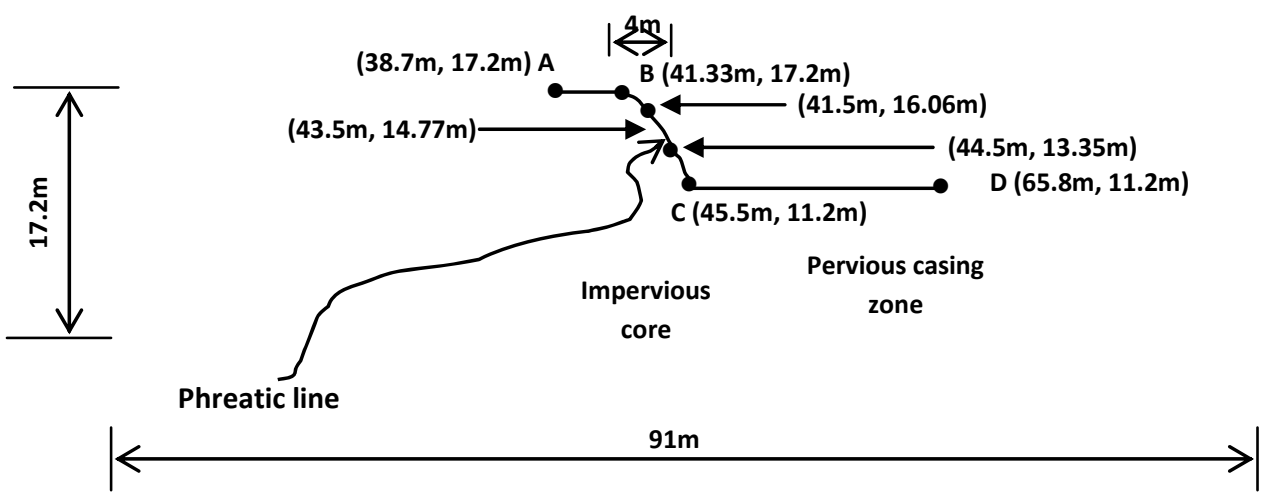

Fig.1. Seepage line (ABCD) within the earthen dam body. 


\section{Details of the embankment studied}

The section of the embankment chosen in the study is considered to have almost the same geometry as that of the embankment surrounding the Ash Pond of Bakreswar Thermal Power Project situated at Panuria village in Birbhum District, West Bengal, India. This is a zoned type earthen embankment which is constructed to make a reservoir for the disposal of fly ash mixed slurry. The height of the embankment is taken as $18 \mathrm{~m}$. The width of the embankment at the base and at the top is considered as $91 \mathrm{~m}$ and $4 \mathrm{~m}$, respectively. Both the upstream and downstream slopes of the embankment are considered as $2.25 \mathrm{H}: 1 \mathrm{~V}$. At the down stream side, there are two horizontal berms of width $3 m$ at a height of $6 m$ and $12 m$ from the ground level, respectively. A cut-off trench of depth $2 \mathrm{~m}$ is provided. It is considered that the maximum height of fluid level is same as the total height of the embankment. Above the phreatic line, the specific weight of the material is taken as $20.5 \mathrm{kN} / \mathrm{m}^{3}$ with the modulus of elasticity $50.000 \mathrm{kN} / \mathrm{m}^{2}$ and Poisson's ratio 0.35 for the pervious casing zone whereas for the impervious core, the specific weight of the material is taken as 19.8 $\mathrm{kN} / \mathrm{m}^{3}$ with the modulus of elasticity $70.000 \mathrm{kN} / \mathrm{m}^{2}$ and Poisson's ratio 0.48 , respectively. The geometrical configuration of this original existing embankment is shown in Fig.2. Different combinations of material properties have been considered in our previous studies [16] regarding the issue of the occurrence of tension zone where the occurrence of the phreatic line was not considered. For the impervious core below the phreatic line, the specific weight in saturated condition is taken as $20 \mathrm{kN} / \mathrm{m}^{3}$ with a minimum value of the modulus of elasticity $500 \mathrm{kN} / \mathrm{m}^{2}$ and maximum value of Poisson's ratio 0.49 . For the pervious casing zone it is assumed that the material properties below the phreatic line are not changed very much and the specific weight in saturated condition is taken as $21 \mathrm{kN} / \mathrm{m}^{3}$ with the modulus of elasticity $50000 \mathrm{kN} / \mathrm{m}^{2}$ and maximum Poisson's ratio 0.4 . The analyses are repeated by changing the specific weight of both the materials below the seepage line reduced by the specific weight of the water. However, the values of these material properties are well within the range prescribed in the standard literature $[25,26]$. The above studies have been repeated for some modified geometrical cross sections of the earthen dam which are shown in Figs 3, 4 and 5.

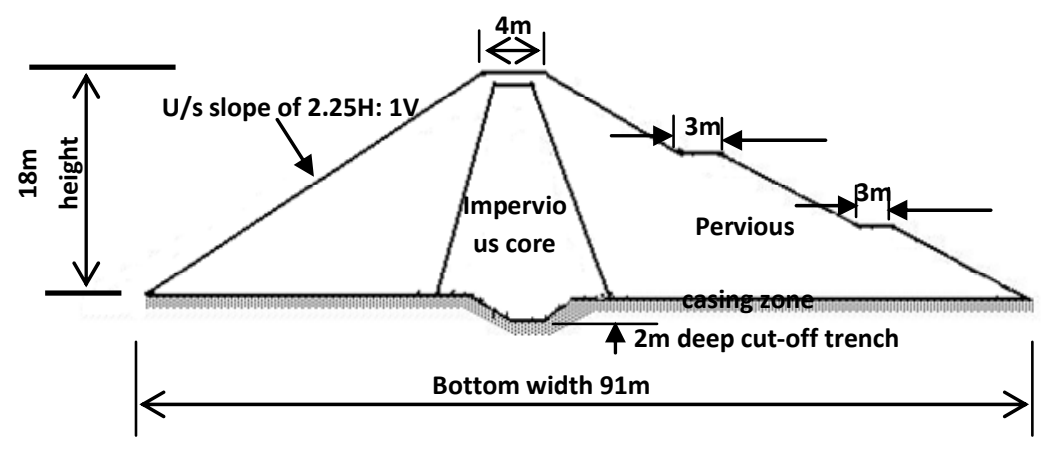

Fig.2. Geometrical cross section of the original embankment surrounding the Ash Pond.

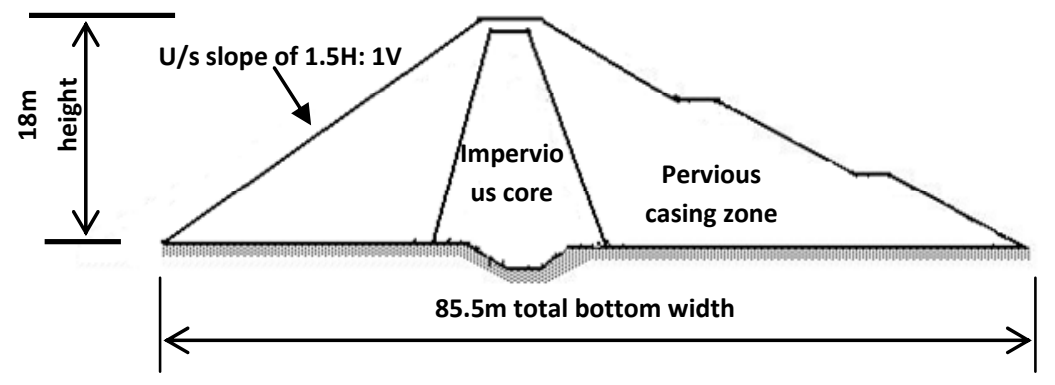

Fig.3. Geometrical cross section of the original embankment section modified with steeper upstream slope. 


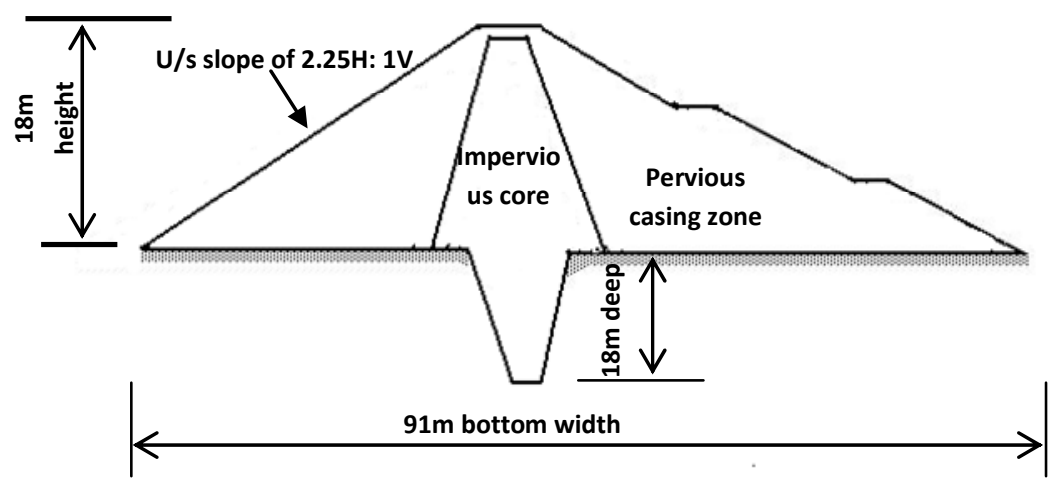

Fig.4. Geometrical cross section of the original embankment section modified with deep cut-off trench.

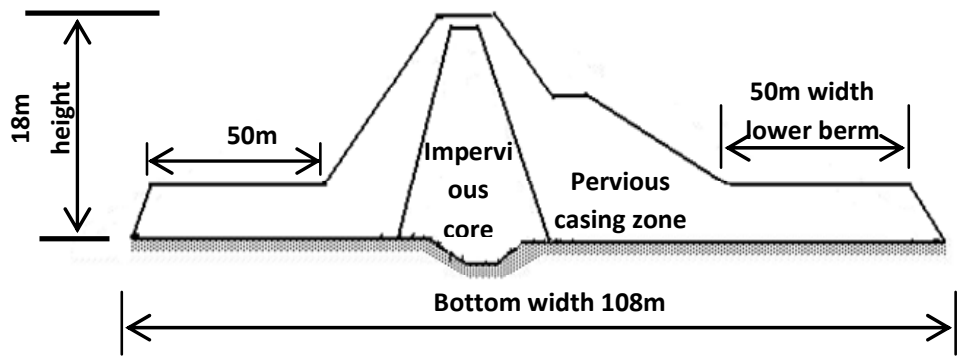

Fig.5. Geometrical cross section of the original embankment section modified with large lower berm.

\section{Results and discussions}

Most of the times, the depth of water in the upstream side is somewhat inbetween the high flood level and empty condition. So, the analysis is carried out to yield the stress distribution pattern within the earthen dams corresponding to the different depths of water in the upstream side. It is found that the results obtained for different depths of water represent more or less the same trend regarding the stress distribution pattern within the dam body. Hence, the representative results corresponding to the three-fourth depth of water at reservoir full condition in the upstream side are presented in the two following subsections, for the sake of brevity.

\subsection{Two-dimensional analysis}

Analyses under static loading, free vibration as well as response spectrum based CQC analysis are conducted through two-dimensional modeling. Results are presented in the following sub-sections.

\subsubsection{Static analysis}

Table 1 represents the principal stresses and the maximum shear stress developed in some key points within the dam body considering the submerged material properties below the phreatic line corresponding to the three-fourth of the depth of water at reservoir full condition in the upstream side for the original embankment section. Table 2 represents the values corresponding to the materially nonlinear behaviour. The stress distribution scenario is also attempted to be represented pictorially. For instance, Fig.6 represents the tension zone and the maximum compression zone within the dam body corresponding to the three-fourth of the depth of water at reservoir full condition at the upstream side for the original embankment section considering the material below the phreatic line as in submerged condition. Figure 7 represents the stress distribution pattern for drawdown condition. The study is extended considering the material nonlinear properties of the soil and the results are presented corresponding to the material properties below the phreatic line as in submerged condition. Figure 8 is the pictorial representation of the tensile stress zone and the 
maximum compressive stress zone within the dam body due to materially nonlinear properties of the soil and submerged condition below the phreatic line. Figure 9 shows the plastic zone developed within the dam section. The same trend of stress distribution scenario regarding the issue of the occurrence of tension zone has been observed corresponding to the half, one-half and full upstream depth of water considering the materials below the phreatic line in submerged condition. Hence, all the figures corresponding to this material property are not presented here.

Table 1. Principal stresses and maximum shear stress obtained by 2D finite element based analysis corresponding to reservoir full condition.

\begin{tabular}{|c|c|c|c|c|}
\hline \multirow{2}{*}{ Positions } & \multicolumn{3}{c|}{$\begin{array}{c}\text { Principal stresses }\left(\boldsymbol{S}_{\max }, \boldsymbol{S}_{\min }\right) \text { and maximum } \\
\text { shear stress }\left(\boldsymbol{\tau}_{\max }\right), \boldsymbol{k N / \boldsymbol { m } ^ { 2 }}\end{array}$} \\
\cline { 2 - 5 } & & $\boldsymbol{S}_{\max }$ & $\boldsymbol{S}_{\min }$ & $\tau_{\max }$ \\
\hline \multirow{3}{*}{ Ground Level } & U/S face & -94.74 & -168.75 & +37.01 \\
\cline { 2 - 5 } & Core Heel & -133.15 & -175.76 & +21.31 \\
\cline { 2 - 5 } & Core Toe & -132.54 & -172.46 & +19.96 \\
\cline { 2 - 5 } & D/S face & +0.31 & -0.68 & +0.50 \\
\hline \multirow{4}{*}{ Lower Berm } & U/S face & -92.43 & -168.72 & +38.15 \\
\cline { 2 - 5 } & Mid section & -86.26 & -124.53 & +19.14 \\
\cline { 2 - 5 } & Inner node & -0.92 & -110.75 & +54.92 \\
\cline { 2 - 5 } & Outer node & -0.45 & -27.20 & +13.38 \\
\hline \multirow{3}{*}{ Upper Berm } & U/S face & +16.56 & -168.42 & +92.49 \\
\cline { 2 - 5 } & Mid section & +17.06 & -174.25 & +95.66 \\
\cline { 2 - 5 } & Inner node & -12.54 & -154.89 & +71.18 \\
\cline { 2 - 5 } & Outer node & -25.76 & -152.67 & +63.46 \\
\hline & U/S face & +2.45 & -123.00 & +62.73 \\
\cline { 2 - 5 } & Mid section & +44.34 & +0.03 & +22.16 \\
\cline { 2 - 5 } & D/S face & +39.38 & -1.71 & +20.55 \\
\hline
\end{tabular}

Table 2. Principal stresses and strain along the $x$ and $y$ direction obtained by 2D finite element based analysis corresponding to the nonlinear material properties in reservoir full condition.

\begin{tabular}{|c|c|c|c|c|c|c|}
\hline \multirow{2}{*}{\multicolumn{2}{|c|}{ Positions }} & \multicolumn{3}{|c|}{$\begin{array}{l}\text { Principal stresses }\left(S_{\max }, S_{\min }\right) \text { and } \\
\text { maximum shear stress }\left(\tau_{\max }\right), \mathrm{kN} / \mathrm{m}^{2}\end{array}$} & \multicolumn{2}{|c|}{$\begin{array}{l}\text { Strain along } x\left(\in_{\mathrm{x}}\right) \text { and } y \\
\left(\in_{\mathrm{y}}\right) \text { directions }\end{array}$} \\
\hline & & $S_{\max }$ & $S_{\min }$ & $\tau_{\max }$ & $\epsilon_{\mathrm{x}}$ & $\epsilon_{\mathbf{y}}$ \\
\hline \multirow{4}{*}{$\begin{array}{c}\text { Ground } \\
\text { Level }\end{array}$} & U/S face & -82.03 & -118.34 & +18.16 & $-0.86 e-04$ & $+0.28 e-04$ \\
\hline & Core Heel & -168.35 & -270.65 & +51.15 & $+0.18 e-02$ & $-0.22 e-01$ \\
\hline & Core Toe & -165.73 & -272.55 & +53.41 & $-0.73 e-03$ & $-0.19 e-01$ \\
\hline & $\mathrm{D} / \mathrm{S}$ face & -176.14 & -317.84 & +70.85 & $-0.14 e-17$ & $-0.44 e-06$ \\
\hline \multirow{4}{*}{$\begin{array}{l}\text { Lower } \\
\text { Berm }\end{array}$} & U/S face & -24.25 & -81.98 & +28.87 & $+0.24 e-03$ & $-0.84 e-03$ \\
\hline & Mid section & -50.72 & -55.00 & +2.14 & $+0.26 e-02$ & $-0.89 e-02$ \\
\hline & Inner node & -1.00 & -41.73 & +20.37 & $-0.71 e-03$ & $+0.36 e-03$ \\
\hline & Outer node & -0.33 & -12.62 & +6.15 & $-0.17 e-03$ & $+0.62 e-04$ \\
\hline \multirow{4}{*}{$\begin{array}{l}\text { Upper } \\
\text { Berm }\end{array}$} & U/S face & -91.87 & -126.67 & +17.40 & $-0.41 e-03$ & $-0.88 e-03$ \\
\hline & Mid secti & -45.67 & -93.52 & +23.93 & $-0.17 e-02$ & $+0.16 e-02$ \\
\hline & Inner node & +5.42 & -56.06 & +30.74 & $+0.40 e-03$ & $-0.16 e-03$ \\
\hline & Outer node & -12.48 & -73.52 & +30.52 & $+0.78 e-04$ & $-0.4 e-04$ \\
\hline \multirow{3}{*}{$\begin{array}{l}\text { Crest } \\
\text { Level }\end{array}$} & U/S face & +4.71 & -80.40 & +42.56 & $-0.14 e-02$ & $+0.98 e-03$ \\
\hline & Mid section & +47.04 & +1.02 & +23.01 & $-0.18 e-02$ & $+0.78 e-03$ \\
\hline & $\mathrm{D} / \mathrm{S}$ face & +18.50 & +1.31 & +8.60 & $-0.11 e-02$ & $+0.57 e-03$ \\
\hline
\end{tabular}




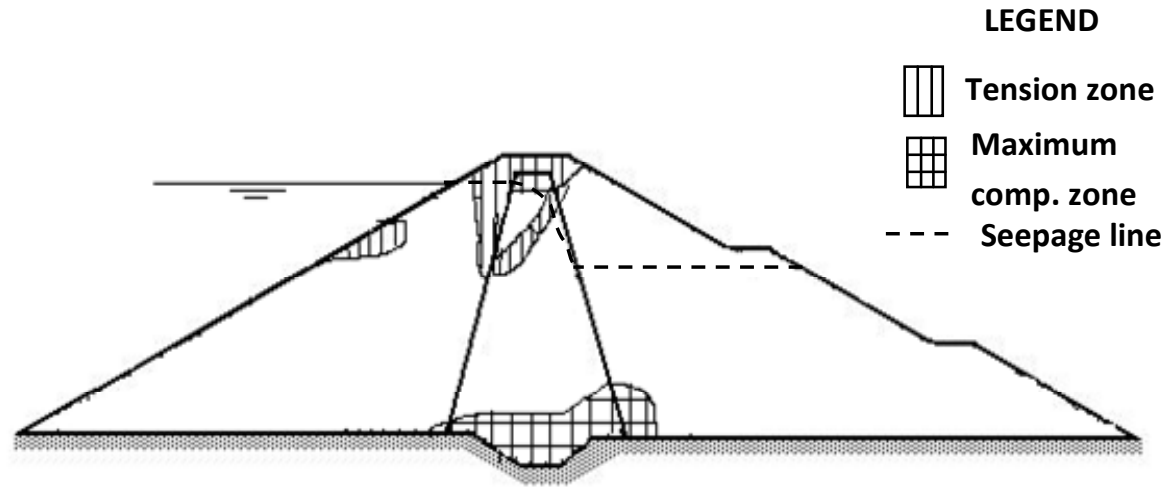

Fig.6. Maximum compressive and tensile principal stress zone obtained by 2D finite element analysis for the original embankment section corresponding to reservoir full condition.

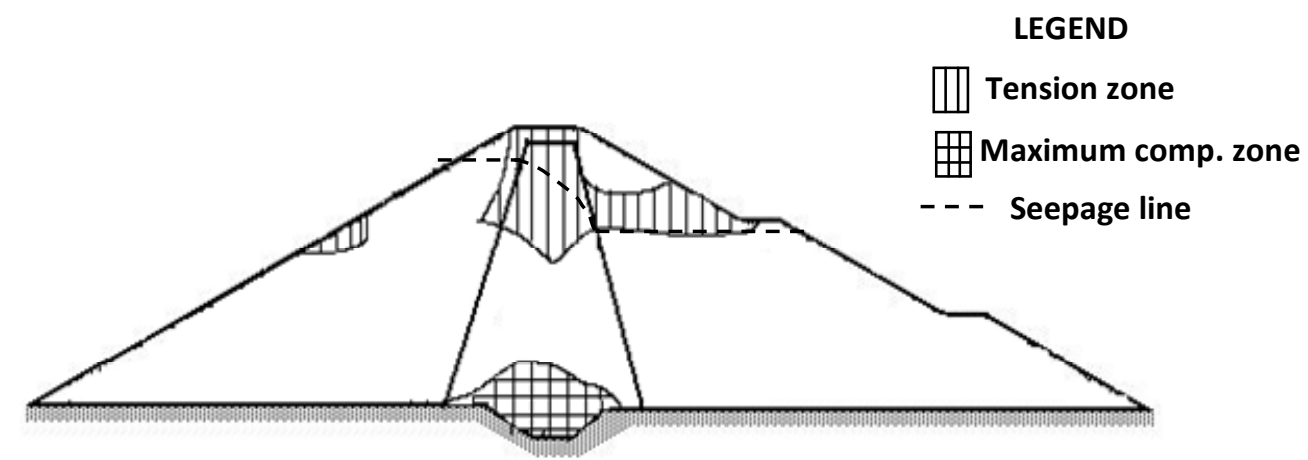

Fig.7. Maximum compressive and tensile principal stress zone obtained by 2D finite element analysis for the original embankment section corresponding to draw down condition.

Figure 6 shows that almost all the tension zone is concentrated around the phreatic line approximately in the middle of the dam body between the upper berm and lower berm position of the dam cross section. This tension zone is also observed to extend below the phreatic line. A small tension zone is also found to occur at the crest level as well as at the upper berm position. Within the tension zones, the range of tensile stress varies from 3 to $5 \mathrm{kN} / \mathrm{m}^{2}$ while the maximum tensile stress varies from 20 to $25 \mathrm{kN} / \mathrm{m}^{2}$. The maximum compressive stress varies from $-150 \mathrm{kN} / \mathrm{m}^{2}$ to $-250 \mathrm{kN} / \mathrm{m}^{2}$. Since the tension zone exists below the phreatic line, soil will be in a very loose condition in that portion. If a small crack is developed, piping will occur through this crack within the dam body due to the presence of water in that zone. This may lead to failure of earthen dams. This may be a probable explanation of the piping failure of many earthen dams due to rise of water level during flooding. It is observed from Fig.7 that the tension zone exists around the phreatic line and the nature of the stress distribution pattern is more or less the same as found in Fig.6. Figure 9 points out that the plastic zone initiates below the phreatic line at the junction of the two materials and extends below the seepage line. Hence, it is clear that the issue of the occurrence of tension zone within the dam body as well as below the phreatic line is not altered even after the shear yielding of the materials. 


\section{LEGEND}

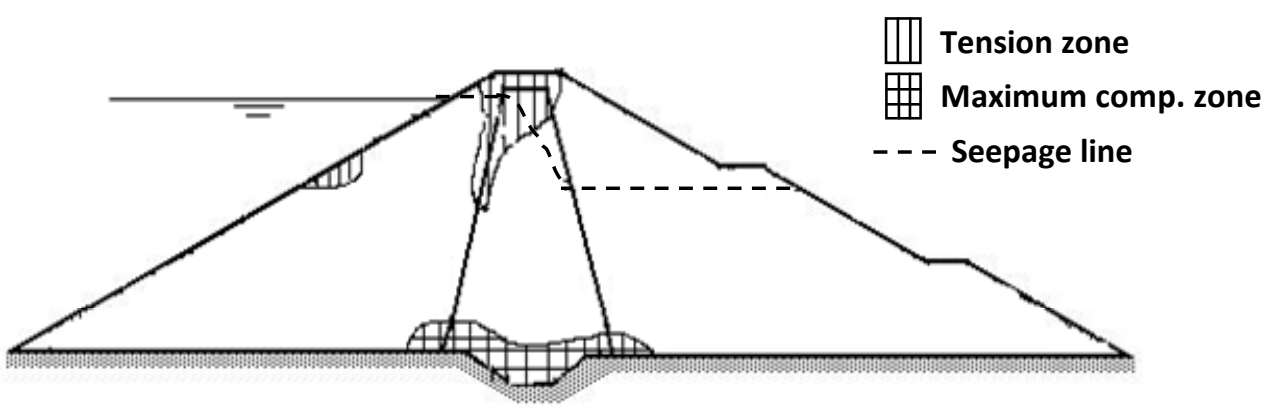

Fig.8. Tension zone and maximum compression zone obtained by 2D finite element analysis taking material nonlinear property for the original embankment section surrounding the Ash Pond.

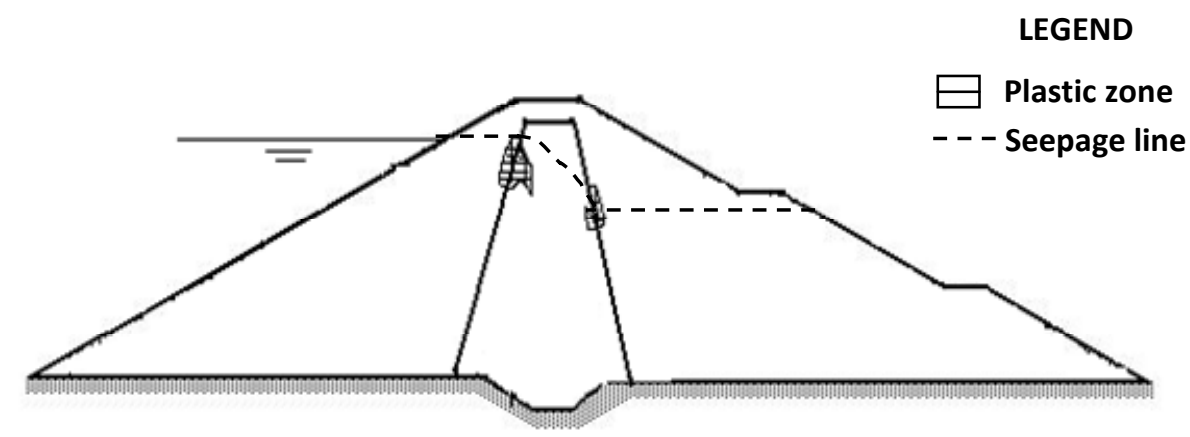

Fig.9. Plastic zone within the dam body as obtained by 2D finite element analysis taking material nonlinear property for the original embankment section surrounding the Ash Pond.

The study has further been extended to modify the geometrical cross section of the earthen dam through changing the upstream slope, deep cut-off trench and large widened lower berm. All the above studies are repeated considering the occurrence of the phreatic line for each of the cases to see whether these changed sections exhibit any considerable alteration in the stress distribution pattern. It is seen that the stress distribution scenario is only marginally changed as compared to the original section even after the consideration of the occurrence of the phreatic line. Hence, these case studies are not presented in detail for the sake of brevity.

\subsubsection{Mode shapes}

First few mode shapes obtained from the two-dimensional analysis show the lateral expansion of the dam section. The same has been found in the three-dimensional analysis and explained in detail in the relevant subsection. Hence, for the sake of conciseness this issue is not elaborated in detail in this subsection.

\subsubsection{Results of CQC analysis}

Table 3 shows the principal stresses and maximum shear stress at different key points of the original embankment section corresponding to the three-fourth of the depth of water at reservoir full condition at the upstream side for the material properties below the phreatic line in submerged condition. Figure 10 shows the location of the maximum tension zone and compression zone developed within the dam body obtained due to seismic forces through CQC method in the same condition. It is observed from Tab.3 that the maximum principal stress is positive at all the nodes in different sections. This implies that the tension 
probably occurs at most of the points in the dam section. However, Fig.10 shows that there is a small compression zone almost all of which occurs at the downstream side extended both above and below the phreatic line. In a very small region at the crest level, the compressive stress is also found to occur. The maximum tension zone is located below the phreatic line approximately at the middle of the dam section which is extended up to the bottom level of the dam. The portion of Fig.10 which is not marked by hatching also shows the location of the tension zone. It seems that the embankment section is more vulnerable during earthquake because a slight shaking may create tension crack below the phreatic line. Piping will start occurring through this crack within the zone below the phreatic line which may create ultimate failure of earthen dams. Hence, apart from the structural failure of earthen dams during earthquake, piping failure may also be a likely phenomenon due to the occurrence of tension.

Table 3. Principal stresses and maximum shear stress in 2D finite element modeling obtained by seismic analysis based on CQC method in reservoir full condition.

\begin{tabular}{|c|c|c|c|c|}
\hline \multirow{2}{*}{\multicolumn{2}{|c|}{ Positions }} & \multicolumn{3}{|c|}{$\begin{array}{c}\text { Principal stresses }\left(S_{\max }, S_{\min }\right) \text { and maximum } \\
\text { shear stress }\left(\tau_{\max }\right), \mathrm{kN} / \mathrm{m}^{2}\end{array}$} \\
\hline & & \multirow{2}{*}{$\begin{array}{c}\boldsymbol{S}_{\max } \\
+0.142\end{array}$} & \multirow{2}{*}{$\begin{array}{c}\boldsymbol{S}_{\min } \\
-0.05\end{array}$} & \multirow{2}{*}{$\begin{array}{c}\tau_{\max } \\
+0.096\end{array}$} \\
\hline \multirow{4}{*}{ Ground Level } & U/S face & & & \\
\hline & Core Heel & +0.762 & -2.762 & +1.762 \\
\hline & Core Toe & +1.042 & -4.751 & +2.896 \\
\hline & $\mathrm{D} / \mathrm{S}$ face & +0.012 & -0.017 & +0.015 \\
\hline \multirow{4}{*}{ Lower Berm } & U/S face & +0.001 & -0.43 & +0.216 \\
\hline & Mid section & +1.47 & -0.57 & +1.020 \\
\hline & Inner node & +10.40 & +0.78 & +4.810 \\
\hline & Outer node & +0.44 & -0.009 & +0.225 \\
\hline \multirow{4}{*}{ Upper Berm } & U/S face & +0.001 & -6.08 & +3.041 \\
\hline & Mid section & +7.04 & +1.87 & +2.585 \\
\hline & Inner node & -0.98 & -14.77 & +6.895 \\
\hline & Outer node & +0.861 & -0.02 & +0.441 \\
\hline \multirow{3}{*}{ Crest Level } & U/S face & +2.00 & +0.03 & +0.985 \\
\hline & Mid section & +42.11 & +1.63 & +20.24 \\
\hline & $\mathrm{D} / \mathrm{S}$ face & +0.52 & +0.002 & +0.259 \\
\hline
\end{tabular}

LEGEND

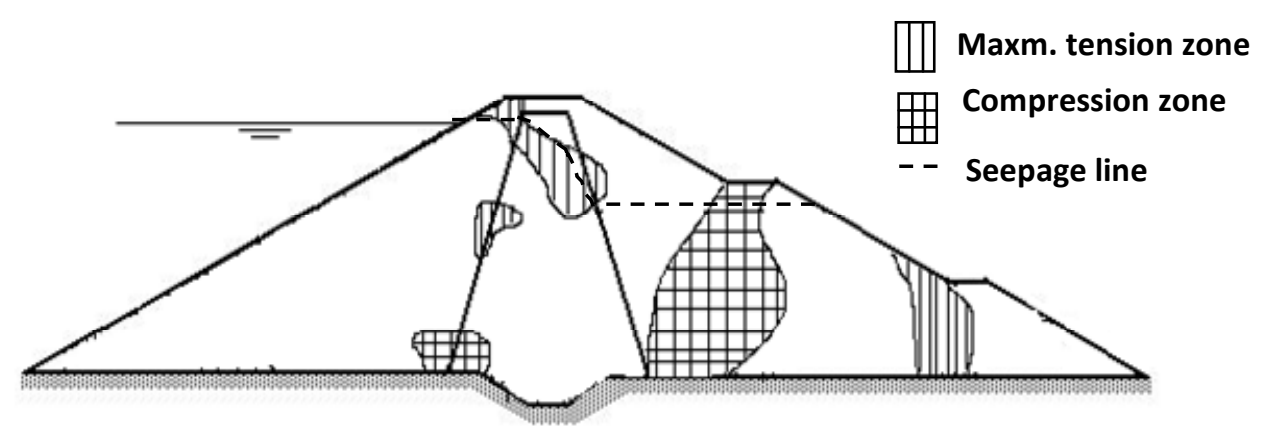

Fig.10. Maximum tension zone and compression zone obtained by 2D finite element based CQC analysis for the original embankment section surrounding the Ash Pond in reservoir full condition. 


\subsection{Three-dimensional analysis}

A three-dimensional analysis is carried out by ten-nodded tetrahedron element. The Dam section is modeled along the straight geometry as well as curvilinear geometry in plan to have an idea whether the curved geometry in plan may influence the stress distribution scenario within the dam body. The observations regarding the stress distribution pattern are more or less the same for these two cases and hence the results corresponding to the straight geometry in plan are presented in the following sub-sections.

\subsubsection{Static analysis}

Table 4 represents the principal stresses and the maximum shear stress developed in some sections within the dam body corresponding to the material properties below the phreatic line in submerged condition for the three-fourth of the depth of water at reservoir full condition in the upstream side for the original embankment section. Table 5 represents the values of principal stresses and strains along $x, y$ and $z$ directions corresponding to the material nonlinear properties. Figure 11 shows the tension zone and the maximum compression zone within the dam body corresponding to the three-fourth of the depth of water at reservoir full condition at the upstream side for the original embankment section when the materials below the phreatic line considered is in submerged condition. The study is extended taking the materially nonlinear properties of the soil and the material below the phreatic line is considered to be in submerged condition. Figure 12 is the pictorial representation of the tensile stress zone and the maximum compressive stress zone within the dam body of a typical intermediate section when analyzed by considering the material nonlinear properties of the soil. Figure 13 shows the plastic zone in a typical intermediate section within the dam body.

Table 4. Principal stresses and maximum shear stress obtained by 3D finite element based analysis in reservoir full condition for a typical intermediate section of the original embankment surrounding the Ash Pond.

\begin{tabular}{|c|c|c|c|c|c|}
\hline \multirow{2}{*}{\multicolumn{2}{|c|}{ Positions }} & \multicolumn{4}{|c|}{$\begin{array}{c}\text { Principal stresses }\left(S_{1}, S_{2} \text { and } S_{3}\right) \text { and maximum shear stress } \\
\left(\tau_{\max }\right), \mathrm{kN} / \mathrm{m}^{2}\end{array}$} \\
\hline & & $S_{1}$ & $S_{2}$ & $S_{3}$ & $\tau_{\max }$ \\
\hline \multirow{4}{*}{$\begin{array}{c}\text { Ground } \\
\text { Level }\end{array}$} & U/S face & +21.27 & -12.76 & -103.62 & +62.45 \\
\hline & Core Heel & -149.87 & -149.92 & -254.87 & +52.50 \\
\hline & Core Toe & -148.41 & -147.52 & -256.97 & +54.28 \\
\hline & $\mathrm{D} / \mathrm{S}$ face & +4.75 & -2.86 & -82.86 & +43.81 \\
\hline \multirow{4}{*}{$\begin{array}{l}\text { Lower } \\
\text { Berm }\end{array}$} & U/S face & +3.00 & -12.42 & -27.86 & +15.43 \\
\hline & Mid section & -48.76 & -49.23 & -54.67 & +2.96 \\
\hline & Inner node & -2.73 & -33.05 & -94.23 & $\begin{array}{r}+45.75 \\
\end{array}$ \\
\hline & Outer node & -0.64 & -2.06 & -15.04 & +7.20 \\
\hline \multirow{4}{*}{$\begin{array}{l}\text { Upper } \\
\text { Berm }\end{array}$} & U/S face & -63.38 & -64.75 & -169.84 & +53.23 \\
\hline & Mid section & -42.16 & -94.63 & -111.53 & +34.69 \\
\hline & Inner node & +27.55 & -0.76 & -3.17 & +15.36 \\
\hline & Outer node & -12.65 & -65.98 & -79.65 & +33.50 \\
\hline \multirow{3}{*}{$\begin{array}{l}\text { Crest } \\
\text { Level }\end{array}$} & U/S face & +20.10 & -25.67 & -142.64 & +81.37 \\
\hline & Mid section & $\begin{array}{l}+43.76 \\
\end{array}$ & -80.87 & -121.53 & $\begin{array}{l}+82.65 \\
\end{array}$ \\
\hline & $\mathrm{D} / \mathrm{S}$ face & +9.65 & -10.62 & -107.86 & +58.76 \\
\hline
\end{tabular}


Table 5. Principal stresses and maximum shear stress obtained by 3D finite element based analysis corresponding to the nonlinear material properties in reservoir full condition for a typical intermediate section of the original embankment surrounding the Ash Pond.

\begin{tabular}{|c|c|c|c|c|c|c|c|c|}
\hline \multirow{2}{*}{\multicolumn{2}{|c|}{ Positions }} & \multicolumn{4}{|c|}{$\begin{array}{l}\text { Principal stresses }\left(S_{1}, S_{2} \text { and } S_{3}\right) \text { and } \\
\text { maximum shear stress }\left(\tau_{\max }\right), \mathrm{kN} / \mathrm{m}^{2}\end{array}$} & \multicolumn{3}{|c|}{$\begin{array}{c}\text { Strain along } x\left(\in_{x}\right), \mathrm{y}\left(\in_{y}\right) \text { and } z \\
\left(\in_{z}\right) \text { directions }\end{array}$} \\
\hline & & $\mathbf{S}_{1}$ & $\mathbf{S}_{2}$ & $\mathbf{S}_{\mathbf{3}}$ & $\tau_{\max }$ & $\epsilon_{\mathrm{x}}$ & $\epsilon_{\mathrm{y}}$ & $\epsilon_{\mathrm{z}}$ \\
\hline \multirow{4}{*}{$\begin{array}{c}\text { Ground } \\
\text { Level }\end{array}$} & U/S face & +9.07 & -84.88 & -123.00 & +66.05 & $-0.76 e-04$ & $+0.27 e-04$ & $+0.16 e-04$ \\
\hline & Core Heel & -159.12 & -159.34 & -185.73 & +13.31 & $+0.17 e-02$ & $-0.21 e-01$ & $-0.12 e-01$ \\
\hline & Core Toe & -159.16 & -159.23 & -265.80 & +53.32 & $-0.67 e-03$ & $-0.16 e-01$ & $-0.17 e-01$ \\
\hline & $\mathrm{D} / \mathrm{S}$ face & +2.01 & -5.07 & -14.71 & +8.36 & $-0.24 e-17$ & $-0.34 e-06$ & $-0.42 e-06$ \\
\hline \multirow{4}{*}{$\begin{array}{l}\text { Lower } \\
\text { Berm }\end{array}$} & U/S face & +2.75 & -80.51 & -128.78 & +65.76 & $+0.25 e-03$ & $-0.74 e-03$ & $-0.83 e-03$ \\
\hline & $\begin{array}{c}\text { Mid } \\
\text { section }\end{array}$ & -57.63 & -48.12 & -153.87 & +48.12 & $+0.16 e-02$ & $-0.78 e-02$ & $-0.75 e-02$ \\
\hline & $\begin{array}{l}\text { Inner } \\
\text { node }\end{array}$ & +2.40 & -7.77 & -24.86 & +13.63 & $-0.69 e-03$ & $+0.35 e-03$ & $+0.26 e-03$ \\
\hline & $\begin{array}{l}\text { Outer } \\
\text { node }\end{array}$ & -0.64 & -5.52 & -15.30 & +7.33 & $-0.13 e-03$ & $+0.57 e-04$ & $+0.59 e-04$ \\
\hline \multirow{4}{*}{$\begin{array}{l}\text { Upper } \\
\text { Berm }\end{array}$} & U/S face & -63.65 & -93.78 & -170.81 & +53.58 & $-0.38 e-03$ & $-0.79 e-03$ & $-0.78 e-03$ \\
\hline & $\begin{array}{c}\text { Mid } \\
\text { section }\end{array}$ & -43.25 & -94.37 & -112.34 & +34.55 & $-0.24 e-02$ & $+0.14 e-02$ & $+0.15 e-02$ \\
\hline & $\begin{array}{l}\text { Inner } \\
\text { node }\end{array}$ & -12.65 & -85.64 & -107.52 & +47.44 & $+0.37 e-03$ & $-0.17 e-03$ & $-0.17 e-03$ \\
\hline & $\begin{array}{l}\text { Outer } \\
\text { node }\end{array}$ & +14.64 & +0.36 & -13.30 & +13.97 & $+0.65 e-04$ & $-0.35 e-04$ & $-0.32 e-04$ \\
\hline \multirow{3}{*}{$\begin{array}{l}\text { Crest } \\
\text { Level }\end{array}$} & U/S face & +12.07 & -41.05 & -130.00 & +71.04 & $-0.16 e-02$ & $+0.76 e-03$ & $+0.95 e-03$ \\
\hline & $\begin{array}{l}\text { Mid } \\
\text { section }\end{array}$ & +44.86 & -67.75 & -119.54 & +82.20 & $-0.17 e-02$ & $+0.72 e-03$ & $+0.75 e-03$ \\
\hline & $\mathrm{D} / \mathrm{S}$ face & +17.07 & +7.00 & -7.28 & +12.18 & $-0.21 e-02$ & $+0.57 e-03$ & $+0.40 e-03$ \\
\hline
\end{tabular}

Figure 11 implies that almost the whole tension zone is concentrated around the phreatic line approximately in the middle of the dam body between the upper berm and lower berm position of the dam cross section. This tension zone is also observed to extend below the phreatic line. A small tension zone is also found to occur at the crest level as well as at the upper berm position. The value of the maximum tensile stress is approximately 30 to $45 \mathrm{kN} / \mathrm{m}^{2}$ but in most of the portion of the tension zone, the range of tensile stress varies from 2 to $3.5 \mathrm{kN} / \mathrm{m}^{2}$. The maximum compressive stress varies from $-250 \mathrm{kN} / \mathrm{m}^{2}$ to $-350 \mathrm{kN} / \mathrm{m}^{2}$ and this maximum compression zone is concentrated at the cut-off trench position. It is observed from Fig.12 that the tension zone exists around the phreatic line and the nature of the stress distribution pattern is more or less the same as found in Fig. 11 even when it is analyzed considering the material nonlinear properties. In this case, the maximum tensile stress varies from 20 to $40 \mathrm{kN} / \mathrm{m}^{2}$ whereas the maximum compressive stress varies from -200 to $-300 \mathrm{kN} / \mathrm{m}^{2}$. Figure 13 points out that the plastic zone begins below the phreatic line at the junction of the two materials and extends towards the downward direction. Hence, it is clear that the issue of the occurrence of tension zone below the phreatic line is still pertinent though the shear yielding of the materials takes place. This indicates that the shear yielding does not release tension. Now, the geometrical cross section of the earthen dam is modified with the steeper upstream slope, deep cut-off trench and large widened lower berm. All the above studies are repeated considering the occurrence of the phreatic line for each of the modified sections to see whether these changed sections may alter the stress distribution pattern. It is seen that the stress distribution scenario is not changed as compared to the same in the original section. Hence, these issues are not discussed in detail for the sake of brevity. 


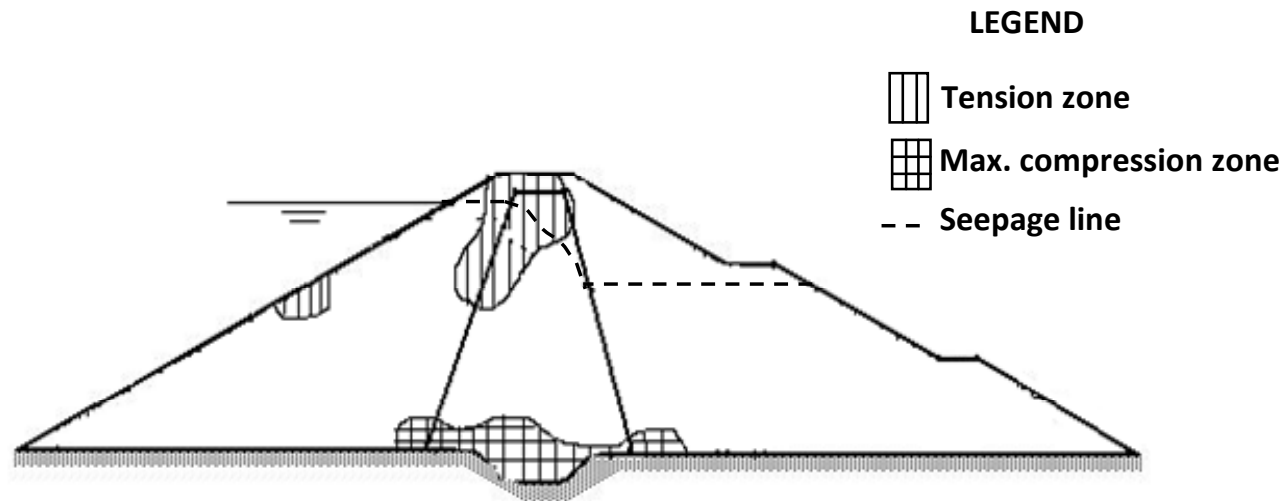

Fig.11. Tension zone and maximum compression zone obtained by 3D finite element analysis in a typical intermediate section of the original embankment corresponding to reservoir full condition.

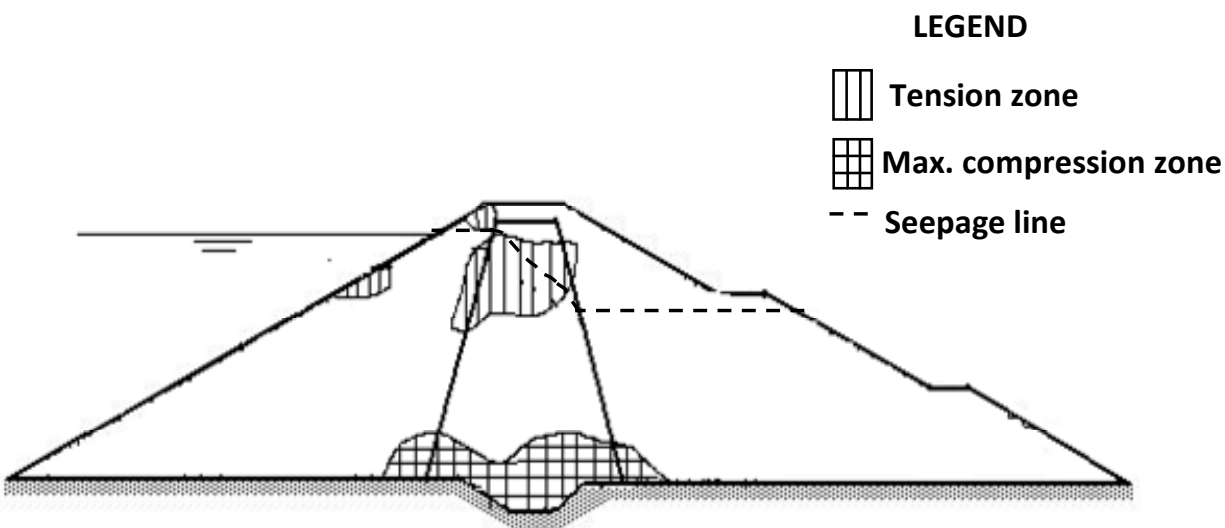

Fig.12. Tension zone and maximum compression zone obtained by 3D finite element analysis considering material nonlinear properties for a typical intermediate section of the original embankment corresponding to reservoir full condition.

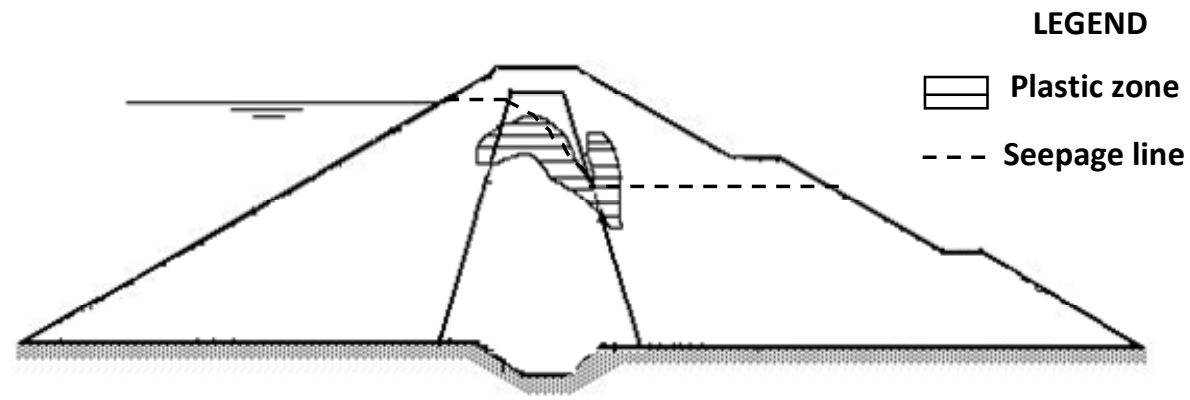

Fig.13. Plastic zone obtained by 3D finite element analysis considering the material nonlinear properties of a typical intermediate section for the original embankment corresponding to reservoir full condition.

\subsubsection{Mode shapes}

Figure 14 represents the mode shapes corresponding to first nine natural periods for the original embankment section modeled along straight geometry in plan for the material properties below the phreatic line in submerged condition. Figure 14 shows the deformation pattern of the upper portion of the earthen dams. It is clear from the above figure that the tendency of the deformation of the crest level may invite the occurrence of a longitudinal crack at the upper portion of earthen dams. This observation also clearly 
explains the crest failure of earthen dams due to earthquake as observed in the last Bhuj earthquake available in the website [26]. The same phenomenon was observed in the previous study which was carried out without considering the occurrence of the phreatic line.

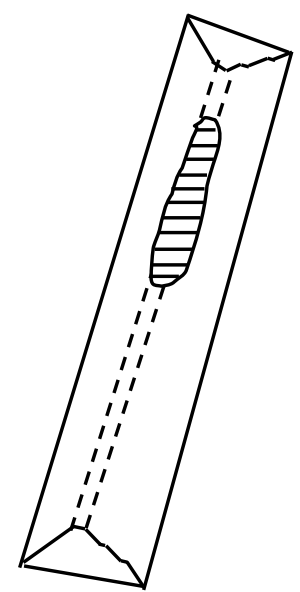

Mode 1; Freq. 0.622

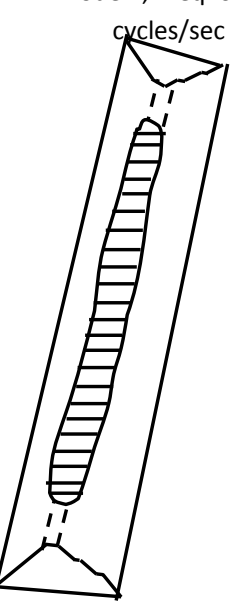

Mode 5; Freq. 0.647 cycles/sec
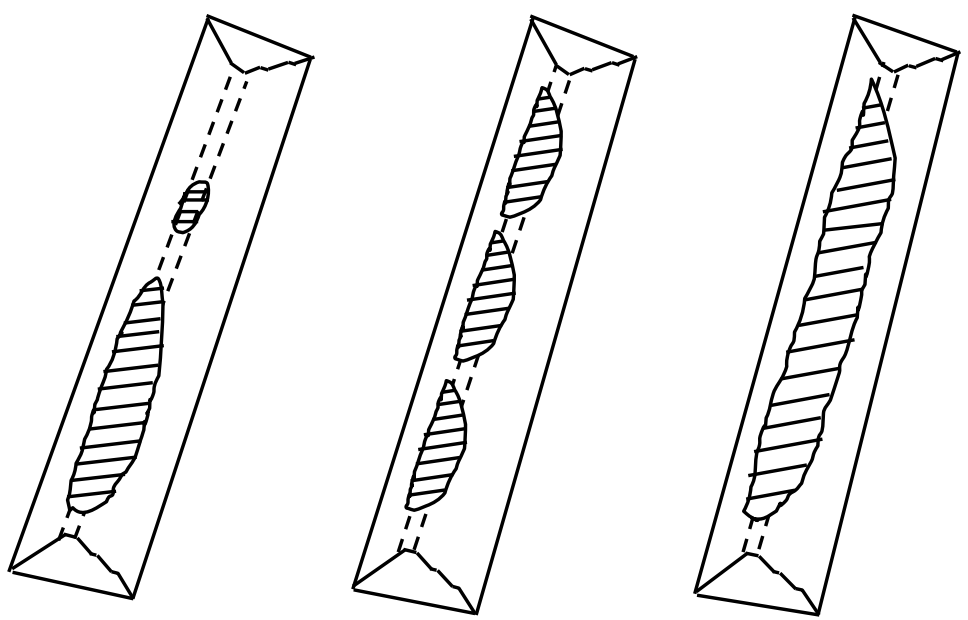

Mode 2; Freq. 0.623

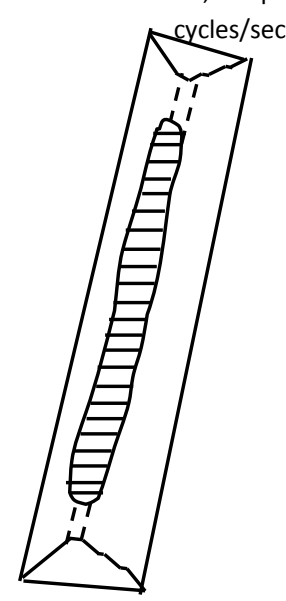

Mode 6; Freq. 0.649 cycles/sec

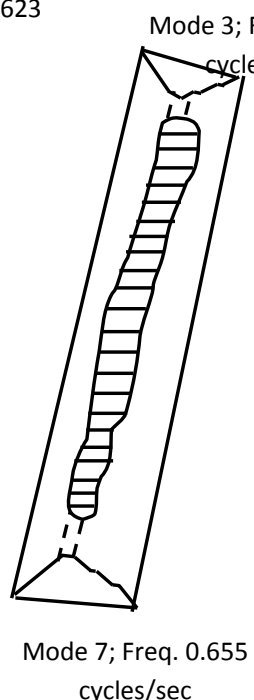

cycles/sec

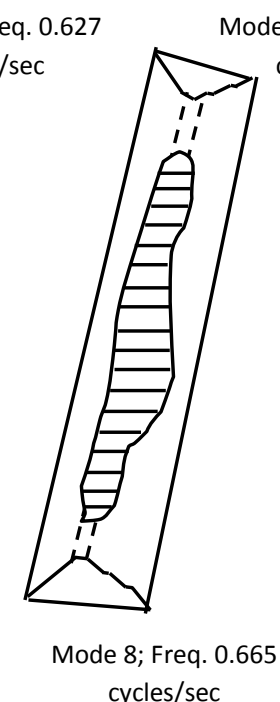

cycles/sec
Mode 4; Freq. 0.634

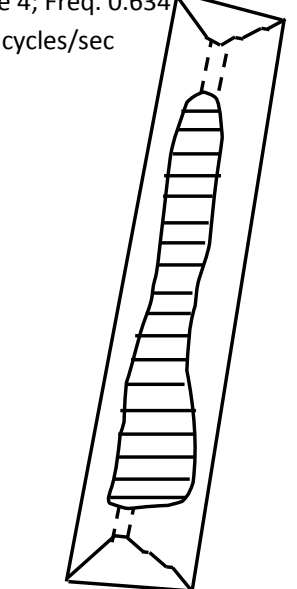

Mode 9; Freq. 0.677 cycles/sec

Fig.14. Mode shapes obtained by 3D finite element based analysis for the original embankment. Hatching portion shows the deformation zone at the crest level in the respective modes.

\subsubsection{Results of CQC analysis}

Table 6 represents the principal stresses and maximum shear stress at different key points of a typical intermediate section of the original earthen embankment with three-fourth of the depth of water at reservoir full condition at the upstream side corresponding to the material properties below the phreatic line in submerged condition. Figure 15 shows the location of the maximum tension zone and compression zone developed in a typical intermediate section within the dam body obtained by CQC analysis corresponding to the material properties below the phreatic line in submerged condition. It is seen from Fig. 15 that almost the whole compression zone occurs at the downstream side extended above and below the phreatic line. In a very small region at the crest level, the compressive stress zone is also found to occur. The maximum tension zone is generated below the phreatic line approximately at the middle of the dam section which is extended up to the ground level of the dam. In Fig.15, the area not marked with any hatching also carries tension while 
the region carrying maximum tension is only marked. It is clear that slight shaking during earthquake may induce the tension crack as the soil cannot withstand any tensile stress.

Table 6. Principal stresses and maximum shear stress obtained by 3D finite element based CQC analysis in reservoir full condition for a typical intermediate section of the original embankment surrounding the Ash Pond.

\begin{tabular}{|c|c|c|c|c|c|}
\hline \multirow{2}{*}{\multicolumn{2}{|c|}{ Positions }} & \multicolumn{4}{|c|}{$\begin{array}{c}\text { Principal stresses }\left(S_{1}, S_{2} \text { and } S_{3}\right) \text { and maximum } \\
\text { shear stress }\left(\tau_{m x}\right), k N / m^{2}\end{array}$} \\
\hline & & \multirow{2}{*}{$\begin{array}{c}\frac{\boldsymbol{S}_{\boldsymbol{1}}}{+0.10} \\
+0\end{array}$} & \multirow{2}{*}{$\begin{array}{c}\boldsymbol{S}_{2} \\
+0.004\end{array}$} & \multirow{2}{*}{$\begin{array}{c}\boldsymbol{S}_{3} \\
+0.001\end{array}$} & \multirow{2}{*}{$\begin{array}{c}\tau_{\max } \\
+0.050\end{array}$} \\
\hline \multirow{4}{*}{$\begin{array}{c}\text { Ground } \\
\text { Level }\end{array}$} & U/S face & & & & \\
\hline & Core Heel & +0.175 & +0.124 & +0.08 & +0.048 \\
\hline & Core Toe & +0.165 & +0.117 & +0.075 & +0.045 \\
\hline & $\mathrm{D} / \mathrm{S}$ face & +0.004 & +0.002 & +0.001 & +0.002 \\
\hline \multirow{4}{*}{$\begin{array}{l}\text { Lower } \\
\text { Berm }\end{array}$} & U/S face & +0.060 & +0.02 & +0.006 & +0.027 \\
\hline & Mid section & +0.07 & +0.02 & +0.003 & +0.034 \\
\hline & Inner node & +0.034 & +0.009 & +0.007 & +0.014 \\
\hline & Outer node & +0.015 & +0.003 & +0.002 & +0.007 \\
\hline \multirow{4}{*}{$\begin{array}{l}\text { Upper } \\
\text { Berm }\end{array}$} & U/S face & +0.067 & +0.034 & +0.018 & +0.025 \\
\hline & Mid section & +0.086 & +0.04 & +0.002 & +0.042 \\
\hline & Inner node & +0.062 & +0.018 & +0.006 & +0.028 \\
\hline & Outer node & +0.060 & +0.021 & +0.013 & +0.024 \\
\hline \multirow{3}{*}{$\begin{array}{l}\text { Crest } \\
\text { Level }\end{array}$} & U/S face & +0.186 & +0.057 & +0.028 & +0.079 \\
\hline & Mid section & +0.167 & +0.082 & +0.039 & +0.064 \\
\hline & $\mathrm{D} / \mathrm{S}$ face & +0.240 & +0.076 & +0.033 & +0.104 \\
\hline
\end{tabular}

LEGEND

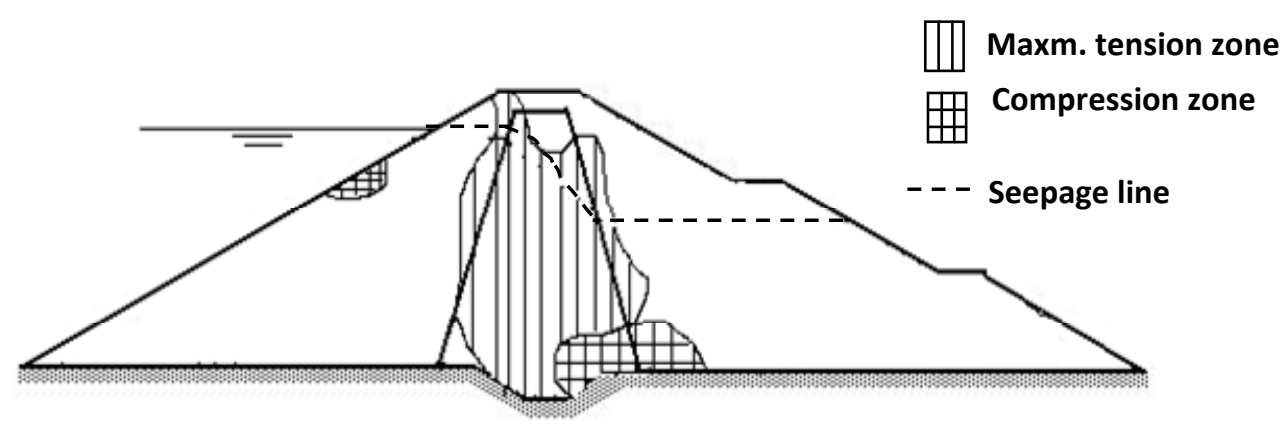

Fig.15. Maximum tension zone and compression zone obtained by 3D finite element based CQC analysis in a typical intermediate section of the original embankment section.

\section{Conclusions}

A few previous studies [15-18] based on computational research have shown that the occurrence of tension zone at the crest level of earthen dams corresponding to different depths of water at the upstream side may be a possible cause of failure of such dams. The present study attempts to find out whether the occurrence of the phreatic line within the dam body has any influence on such observations. Further, an experimental verification of such behaviour under a harmonic loading, with the help of a small scale model has also been made [17]. The study may lead to the following conclusions.

1. The present work considering the occurrence of the phreatic line implies the consideration of material properties in submerged condition below the phreatic line. In this situation, the location of most of the 
tension zones is shifted around the phreatic line. This may lead to a favorable condition for piping. The dynamic analysis also shows more or less the same stress distribution scenario within the dam body. Hence, a slight ground shaking during earthquake excitation will not only cause the structural failure of earthen dams but also invite the piping failure through a widened crack which may be generated in the tension zone near the phreatic line due to shaking.

2. Due to the tendency of lateral extension at the top as understood from the nature of first few mode shapes, the vertical crack is also likely to occur at the crest under seismic ground shaking, even if the submerged zone below the phreatic line is present. The modifications in the configuration of the section of the earthen dam, namely, the change in the upstream slope or provision of deep cut-off trench or provision of large lower berm do not effectively modify the stress distribution scenario as well as dynamic characteristics of earthen dams even after the consideration of the occurrence of the phreatic line within the dam body. The curvilinear geometry along the longitudinal axis also does not seem to change the stress distribution scenario or the dynamic characteristics of the earthen dams.

\section{Nomenclature}

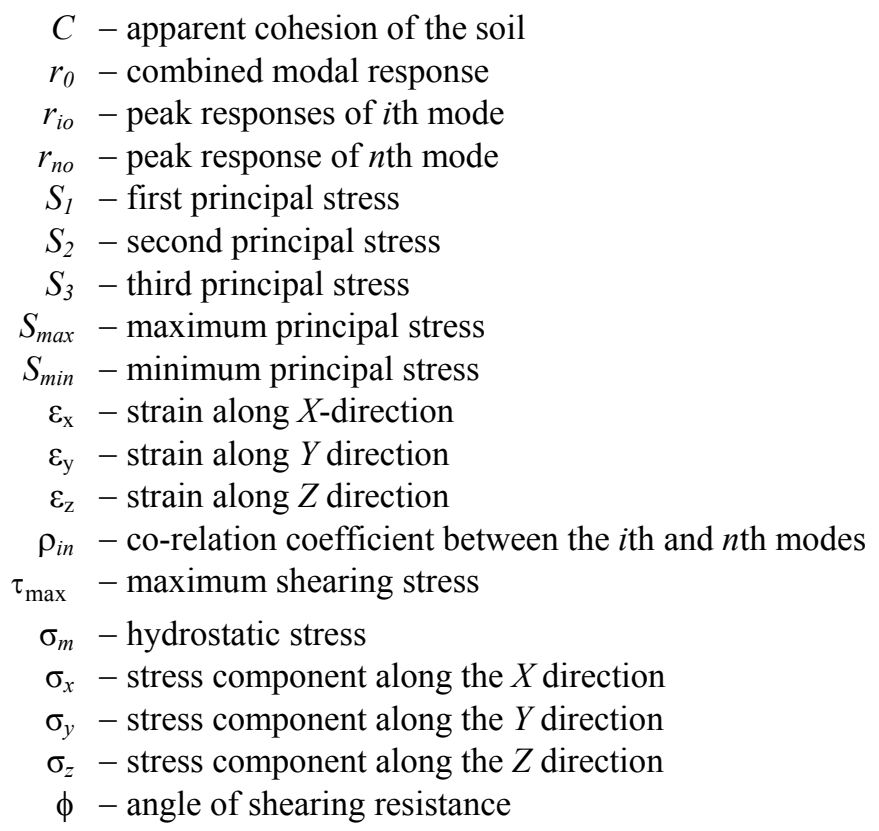

\section{References}

[1] Adhikari D.P. and Chattopadhyay A. (1996): Behaviour of earth and rockfill dam under earthquake. - Proc Symposium on Earthquake Effects on Structures, Plant and Machinery, New Delhi.

[2] Jain S.K. and Lettis W.R. (2001): Preliminary Observations on the Origin and Effect of the January 26, 2001 Bhuj (Gujarat, India) Earthquake". - EERI Special Earthquake Report supported by EERI's learning from Earthquake Project, Funded by National Science Foundation.

[3] Saeed Poorkarimi Kokaneh, Shahram Maghsoodian, Hossein MolaAbasi and Afshin Kordnaeij (2013): Seepage evaluation of an earth dam using Group Method of Data Handling (GMDH) type neural network: A case study. Scientific Research and Essays, vol.8, No.3, pp.120-127, (ISSN: 1992-2248).

[4] Sivakumar Babu G. and Srivastava A. (2010): Reliability analysis of earth dams. - J. Geotech. Geoenviron. Eng., ASCE, vol.136, No.7, pp.995-998.

[5] Karimi H., Hasani H. and Mamizadeh J. (2013): Stability of slope and seepage analysis in earth using numerical models (Case Study: Ilam DAM-Iran). - World Applied Sciences Journal 01/2013; vol.21, No.9, pp.1398-1402. 
[6] Fu J.F. and Jin S. (2009): A study on unsteady seepage flow through dam. - Journal of Hydrodynamics, vol.21, No.4, pp.499-504.

[7] Li G.C. and Desai C.S. (1983): Stress and seepage analysis of earthen dams. - Journal of Geotechnical Engineering ASCE, vol.109, pp.946-960.

[8] Griffiths D.V. and Lane P.A. (1999): Slope stability analysis by finite elements. - Geotechnique, vol.49, No.3, pp.387-403.

[9] Zheng H., Liu D.F. and Li C.G. (2005): Slope stability analysis based on elasto-plastic finite element method. - Int. J. Numerical Methods in Engg, vol.64, pp.1871-1888.

[10] Duncan J.M. (1996): State of the Art: Limit equilibrium and finite-element analysis of slopes. - J. Geotech. Eng., ASCE, vol.122, No.7, pp.577-596.

[11] Huy Thanh Pham, Htet Zaw O and Cheng Jing (2013): Stability of slope and seepage analysis in earth dam using numerical finite element model. - Study of Civil Engineering and Architecture (SCEA), vol.2, No.4.

[12] Dhariwal A. and Purohit D.G. (2000): Failure philosophy of embankment dams. - Proceedings of 2000 IGC the Millennium Conference, Mumbai, India.

[13] Huang T.K. (1996): Stability analysis of an earth dam under steady state seepage. - Comput. Struct., vol.58, No.6, pp.1075-1082.

[14] Zeghal M. and Abdel-Ghaffar A.M. (1992): Local-global finite element analysis of the seismic response of earth dams. - Comput. Struct., vol.42, No.4, pp.569-580.

[15] Sarkar P., Dutta S.C. and Nandi N. (2003): A critical review of dam analysis methodologies. - Int. J. App. Mech. Eng., vol.8, No.3, pp.461-482.

[16] Nandi N., Dutta S.C. and Roychowdhury A. (2005): Analysis on shear failure of earthen dams. - International Journal on Dam Engineering, vol.15, No.4, pp.255-282.

[17] Nandi N., Dutta S.C. and Roychowdhury A. (2010): Explanation of seismic failure possibilities through dynamic and response analysis of earthen dams. - International Journal of Dam Engineering, vol.21, No.1, pp 45-67.

[18] Nandi N. (2008): Free vibration characteristics of earthen dams. - International Journal of Mechanics and Solids (ISSN 0973-1881), vol.3, No.1, pp.43-59.

[19] Clough R.W. and Chopra A.K. (1987): Earthquake stress analysis in earthen dams. - J. Eng. Mech. Div. ASCE, vol.92 (EM 2), pp.197-210.

[20] Makdisi F.I. and Seed H.B. (1977): A simplified procedure for estimating earthquake-induced deformations in dams and embankments. - Earthquake Engineering Research Centre, University of California, Berkeley, (UCB/EERC-77/19).

[21] Desai C.S. and Abel J.F. (1987): Introduction to the Finite Element Method. - CBS, India.

[22] Ansys User's Manual for version 5.0, Swanson Analysis Systems, Inc; 1994.

[23] Chopra A.K. (2001): Dynamics and structures. - Pearson education (Singapore) Pte. Ltd., India Branch, Delhi 110092.

[24] Murthy V.N.S. (1989): Soil Mechanics and Foundation Engineering. - Sri Kripa Technical Consultants, Bangalore-560 070.

[25] Bowles J.E. (1996): Foundation Analysis and Design. - McGraw-Hill, Inc. $4^{\text {th }}$ International Edition.

[26] Winterkorn H.F. and Fang H.Y. (1986): Foundation Engineering Hand Book. - Galgotia Book Source, Van Nostrand Reinhold Comp. Inc.

[26] Available in article 'Dams' in the website http://geoinfo.use.edu/gees/Recent EQ/India-Gujarat/Report/dams.

Received: October 1, 2015

Revised: October 16, 2017 